\title{
NILAI- NILAI PENDIDIKAN ISLAM DALAM TRADISI BUBAK KAWAH DI DESA MOROSARI PONOROGO
}

\author{
Syamsul Muqorrobin \\ Institut Agama Islam Sunan Giri Ponorogo \\ Email: syamsulrobin@gmail.com \\ Tamrin Fathoni \\ Institut Agama Islam Sunan Giri Ponorogo \\ Email:tam2fiana@gmail.com \\ Asfahani \\ Institut Agama Islam Sunan Giri Ponorogo \\ Fahan380@gmail.com
}

\begin{abstract}
This study aims to describe the values of Islamic education in the tradition of Bubak Kawah in Morosari Village. The method used is descriptive-qualitative. From the research conducted found that The first value of Islamic education is gratitude to God from the parents of the bride because of God's grace, her child is given the ease to find her soul mate. The second value of Islamic education is the request to God that the bride be given strength, physical and spiritual freshness. The third educational value is can be seen from the various equipment used in the Bubak Kawah event
\end{abstract}

Keywords: Value of Islamic Education, Tradition of Bubak Kawah

\section{PENDAHULUAN}

Melihat dan awal perkembangan semula, mulai proses masuknya Islam ke tanah Indonesia, dan luar Jawa, hingga ke pulau Jawa, proses penyebaran ajaran dan nilainilai Islam, memang terjadi akulturasi antara tradisi orisinalitas penduduk pribumi dengan nilai-nilai Islami, sehingga dengan kebiasaan dan cara pandang inilah, 
bahwasanya kerangka dasarnya dibangun atas dasar-dasar percampuran nilai Islam dan tradisi pribumi menjadi satu kesatuan yang utuh. ${ }^{1}$

Dalam perkembangan dakwah Islam di Indonesia para penyiar Islam mendakwahkan ajaran Islam melalui bahasa budaya, sebagaimana dilakukan oleh para Wali Allah di tanah Jawa. Karena kehebatan Para Wali dalam mengemas ajaran Islam dengan bahasa budaya setempat, sehingga masyarakat tidak sadar bahwa nilai ilahi Islam masuk dan menjadi tradisi dalam kehidupan sehari-hari mereka. ${ }^{2}$

Perkawinan adalah ikatan lahir batin antara pria dengan seorang wanita sebagai suami istri dengan membentuk keluarga. Perkawinan juga merupakan peristiwa yang dianggap penting oleh masyarakat Jawa sebelum kelahiran dan kematian. Masyarakat Jawa memiliki sebuah adat ataupun cara tersendiri dalammelaksanakan upacara perkawinan yang lengkap dengan semua prosesnya masih digunakan dan dilestarikan serta menjadi suatu upacara yang sakral.

Istilah yang kita dengar dalam upacara adat Jawa seperti "Bubak" masih sering kita jumpai di masyarakat terutama di Jawa. Bubak berarti mbukak (membuka). Kawah adalah air yang keluar sebelum kelahiran bayi. Bubak Kawahadalah membuka jalan mantu atau mantu yang pertama. Menurut Sutawijaya dan Yatmana menyatakan bahwa Bubak Kawahadatah upacara adat yang dilaksanakan ketika orangtua mantu pertama atau terakhir. Mantu pertama disebut tumpak punjen, sedangkan mantuterakhir disebut tumplak punjen $).^{3}$

Tradisi Bubak Kawahmerupakan sebuah tradisi yang merupakan salah satu upacara tradisional dari para leluhur yang diwariskan secara turun temurun serta wajib ada dan dilaksanakan dalam sebuah perkawinan dalam tradisi Jawa. Upacara Bubak

\footnotetext{
${ }^{1}$ Faisol, Pendidikan Islam Perspektif, (Jakarta: Quepedia, 2005), hal. 210.

2 Wahyudin, Pendidikan Agama Islam, (Jakarta: Grasindo, 2007), hal. 122.

3 Suwarna Priggawidagda, Tata Upacara Dan Wicana Pengantin Gaya Jogja ,(Jogjakarta: Kanisius, 2006), hal. 275
} 
Kawahbukan merupakan upacara yang biasa namun ritual yang memiliki nilai- nilai pendidikan yang luhur untuk anak yang melangsungkan pernikahan serta untuk kedua orang tua.

Peneliti mengambil upacara khusus yaitu tradisi Bubak Kawah karena menarik, dikatakan sebab sudah banyak generasi muda yang tidak tahu nilai nilai pendidikan Islam dalam tradisi Bubak Kawah. Tugas berikutnya para intelektual Islam adalah menjelaskan secara sistematik dan berkelanjutan upaya penetrasi yang sudah dilakukan oleh para pendahulunya. Integrasi nilai-nilai Islam ke dalam kehidupan bangsa Indonesia ternyata tidak sekedar masuk pada aspek kebudayaan semata, tetapi sudah masuk ke wilayah pendidikan. Sebagai contoh dalam nilai pendidikan keluarga (akhwalul syahsiyyah), masalah pernikahan. Nilai-nilai Islam telah masuk ke wilayah hukum yang berlaku di Indonesia. ${ }^{4}$

Perkembangan zaman juga membawa perubahan pada tradisi Bubak Kawah, banyak masyarakat yang hanya melaksanakan tradisi Bubak Kawah tanpa mengetahui nilai- nilai yang terkandung di dalamnya. Serta dengan minimnya pengetahuan tentang tradisi Bubak Kawah membawa dampak banyak generasi muda yang tidak tahu dan tidak mengerti Bubak Kawahitu seperti apa. Peneliti memilih lokasi penelitian di desa Morosari karena desa ini telah lama melaksanakan tradisi Bubak Kawah sampai sekarang. Peneliti ingin memperkenalkan pada generasi penerus bahwa kebudayaan Bubak Kawahmasih ada walaupun dalam pelaksanaannya terjadi perubahan akibat tergeser oleh globalisasi dan menjadikan sedikit berkurang kesakralan dan nilai yang terkandung dalam setiap prosesi Bubak Kawahyang syarat akan memiliki makna, nilai serta doa.

\footnotetext{
${ }^{4}$ Wahyudin, Pendidikan Agama Islam, hal. 23.
} 


\section{METODE}

Jenis penelitian ini adalah penelitian kualitatif yang bersumber dari data-data di lapangan yang kemudian dianalisis. Data-data yang diperoleh berupa keterangan, simbol serta perilaku yang dapat diamati dan dijelaskan sesuai kebutuhan penelitian. Lokasi penelitian berada di desa Morosari Kecamatan Sukorejo Kabupaten Ponorogo. Teknik pengumpulan data yang digunakan adalahobservasi, wawancara, dan dokumentasi. Teknik analisis data dalam penelitian ini menggunakan analisis data kualitatif Miles dan Haberman.Miles dan Haberman, mengemukakan aktifitas dalam analisis data kualitatif dilakukan secarainteraktif dan berlangsung secara terusmenerus pada setiap tahapan-tahapan penelitian sampai tuntas, dan datanya sampai jenuh. ${ }^{5}$

\section{PEMBAHASAN}

\section{Nilai Pendidikan Islam}

Nilai dapat diartikan sebagai seperangkat keyakinan dan sikap pribadi seseorang tentang kebenaran, keindahan, dan penghargaan dan suatu pemikiran, objek, atau perilaku yang berorientasi pada tindakan dan pemberian arah serta makna pada kehidupan seseorang. Sedangkan pendidikan Islam memiliki pengertian sesuai yang disampaikan H.M. Chabib Thoha bahwa hakekat pendidikan Islam adalah proses pemeliharaan dan penguatan sifat potensi insani untuk menumbuhkan kesadaran dalam menemukan kebenaran. ${ }^{6}$

Pendidikan Islam pada hakekatnya tidak bertujuan untuk meleburkan sifat dan potensi insani ke dalam sifat dan potensi malakiyah, karena ternyata praduga pada misi

\footnotetext{
${ }^{5}$ Miles, B. Mathew dan Michael Huberman. Analisis DataKualitatif Buku Sumber Tentang Metode-metode Baru (Jakarta: UIP, 1992), hal. 32.

${ }^{6}$ Mimin Emi Suhemi, Etika \& Aplikasi, (Jakarta: EGC, 2002), hal. 19.
} 
kekhalifahan manusia di muka bumi, yang akan menimbulkan penguasaan manusia atas manusia sehingga akhirnya menimbulkan pertumpahan darah dan perusakan di atas dunia $\mathrm{ml}$, mendapatkan reaksi negatif dan Allah SWT. Misi kekhalifahan manusia di muka bumi salah satunya diaplikasikan dalam bentuk pendidikan sebagai wujud konsekuensi dan tanggung Jawab intelektual Adam yang telah dididik oleh Allah SWT untuk menegakkan kebenaran. Pengakuan malaikat atas kebenaran ilmiah (kelebihan intelektualisme Adam) merupakan sikap ibadah (sujud), dan pengingkaran Iblis atas kebenaran ilmiah itu merupakan sikap arogansi dan kekufuran. ${ }^{7}$

Dalam pendidikan Islam terdapat unsur nilai-nilai yang terkandung didalamnya, diantaranya sebagai berikut:

a. Nilai Aqidah

Dalam pembinana nilai-nilai aqidah ini memiliki pengaruh yang luar biasa pada kepribadian anak, pribadi anak tidak akan didapatkan selain dari orang tuanya. Pembinaan tidak dapat diwakili dengan sistim pendidikan yang matang. (Muhammad Nur Abdul Hafizh, 1997). Jadi aqidah adalah sebuah konsep yang mengimani manusia seluruh perbuatan dan prilakunya dan bersumber pada konsepsi tersebut. Aqidah Islam dijabarkan melalui rukun iman dan berbagai cabangnya seperti tauhid uluhiyyah atau penjauhan diri dari perbuatan syirik, aqidah Islam berkaitan pada keimanan.

b. Nilai Ibadah

Dapat dipahami bahwa ibadah merupakan ajaran Islam yang tidak dapat dipisahkan dari keimanan, karena ibadah merupakan bentuk perwujudan dari keimanan. Dengan demikian kuat atau lemahnya ibadah seseorang ditentukan oleh kualitas imannya. Semakin tinggi nilai ibadah yang dimiliki akan semangkin

\footnotetext{
${ }^{7}$ Moch Eksan, Kyai Kelana Biografi KH. Muchid Muzadi ( Yogyakarta : Lkis, 2000), hal. 30.
} 
tinggipula keimanan seseorang. Jadi ibadah adalah cermin atau bukti nyata dari aqidah.

"Ibadah berasal darikata Abd yang berarti pelayan dan budak. Jadi hakikat ibadah adalah penghambaan. Sedangkan dalam arti terminologinya ibadah adalah usaha mengikuti hukum dan aturan- aturan Allah Swt dalam menjalankan kehidupan sesuai dengan perintahnya, mulai dari akil balig sampai meninggal dunia".

c. Nilai Akhlak

Ahmad Amin merumuskan “akhlak ialah ilmu yang menjelaskan arti baik dan buruk, menerangkan apa yang seharusnya dilakukan oleh sebagian manusia kepada yang lainnya, menyatakan tujuan yang harus dituju oleh manusia dalam perbuatan mereka dan menunjukkan jalan untuk melakukan apa yang harus diperbuat. $^{8}$

\section{Tradisi Bubak Kawah}

Menurut Sudaryanto, Bubak berarti mbukak (membuka). Kawah adalah air yang ketuar sebetum kelahiran bayi. Bubak Kawahadalah membuka jalan mantu atau mantu yang pertama. Menurut Sutawijaya dan Yatmana menyatakan bahwa Bubak Kawahadatah upacara adat yang dilaksanakan ketika orangtua mantu pertama atau terakhir. Mantu pertama disebut tumpak punjen, sedangkan mantu terakhir disebut tumplak punjen. Menurut Sudaryanto, Bubak berarti mbukak (membuka). Kawah adalah air yang ketuar sebetum kelahiran bayi. Bubak Kawahadalah membuka jalan mantu atau mantu yang pertama. Menurut Sutawijaya dan Yatmana menyatakan bahwa Bubak Kawahadalah upacara adat yang dilaksanakan ketika orangtua mantu

\footnotetext{
${ }^{8}$ Abdul A'ala Al-Maududi, Dasar-Dasar Islam, (Bandung, Pustaka, 1994), hal, 107.
} 
pertama atau terakhir. Mantu pertama disebut tumpak punjen, sedangkan mantu terakhir disebut tumplak punjen. ${ }^{9}$

Tradisi Bubak Kawah ini memiliki Makna dan tujuan sebagaimana yang disampaikan oleh Suwarna priggawidagda, adalah sebagai berikut:

a. Pernyataan syukur kepada Tuhan bahwa tetah dapat mengawali mantu.

b. Permohonan kepada Tuhan agar pengantin diberikan kekuatan, kesegaran jasmani dan rohani, ayem tentrem.

c. Harapan agar pengantin dikarunial anak.

d. Menunjukkan tanggung Jawab orangtua terhadap putranya. Walaupun susah payah untuk melaksanakan perhelatan, tetapi badan dan pikiran tetap segar bugar seperti segarnya rujak degan.

e. Menunjukkan kepada kerabat tamu bahwa ini perhelatan mantu yang pertama. ${ }^{10}$

Disamping itu, terdapat Peralatan khusus dalam Tradisi Bubak Kawah, yaitu Peralatan atau sesaji terdiri atas kemarang, berisi pisang raja setangkep, gula kelapa setangkep, kelapa satu butir, ayam yang masih kecil, cok bakal, kinarigan, tikar yang masih baru dan dilapisi kain/mori putih, kendhil/klenthing sebanyak tiga buah, kendhil pertama berisi: beras ketan, beras merah, dan dua butir telur; kendhil kedua berisi: buah-buahan dan kue; kendhil ketiga berisi: kelapa muda berisi santan, dan kembar mayang.

Kendhil/klenthing adalah lambang dari cupu manik astagina. Cupu manik astaginamerupakan tempat untuk menyimpan titipan wiji banyu suci purwitasari dari seorang laki-laki kepada istrinya, hal ini yang nanti akan dipergunakan untuk dialog antara ayah dan ibu calon temanten.

Ketan dan beras merah melambangkan rezeki dan berkah, dengan telah dilaksanakannya bubakan diharapkan rezeki dan berkah dari Tuhan Yang Maha Kuasa

\footnotetext{
${ }^{9}$ Suwarna Priggawidagda, Tata Upacara Dan Wicana Pengantin Gaya Jogja, hal. 275

${ }^{10}$ Suwarna Priggawidagda, hal. 275.
} 
bisa lancar, baik rezeki untuk orang tua calon temanten maupun rezeki calon temanten, sedangkan kelapa muda yang diisi santan sebagai gambaran air susu.

Jadi pada acara bubak temanten ada seorang putra menyerahkan kelapa muda kepada ibu, dengan maksud sebagai persembahan seorang putra yang sudah dewasa kepada ibunya, mengingat bahwa pada masa anak-anak disusui oleh ibunya. Telur melambangkan bahwa manusia berasal dari benda yang berwarna merah dan putih. ${ }^{11}$

\section{Profil Desa Morosari}

Menurut cerita pada zama dulu waktu wilayah Morosari masih hutan dan belum diberi nama Morosari ada seroang yang bernama "EYANG NOLO JOYO: babat wilayah tersebut untuk dijadikan tempat tinggal. Beliau adalah seorang yang berilmu dan banyak kelebihan dan masih keturunan salah satu punggawa kerajaan Bantar Angin (Sekarang Somoroto). Beliau juga berjasa pada kerajaan Bantar Angin sehingga diizinkan untuk babat (membuka Wilayah) di Morosari (sekarang) yang waktu itu masih wilayah kekuasaan Bantar Angin.

Secara administratif, Desa Morosari terletak di wilayah Kecamatan Sukorejo Kabupaten Ponorogo dengan posisi dibatasi oleh wilayah desa-desa tetangga. Disebelah Utara berbatasan dengan Desa Karanglo Lor.Di sebelah Barat berbatasan dengan Desa Gabel Kec. Kauman, Kab.Ponorogo. Di sisi Selatan berbatasan dengan Desa Gabel sedangkan di sisi timur berbatasan dengan Desa Sragi Kec. Sukorejo Kab Ponorogo.

Sejarah tradisi Bubak Kawah didesa Morosari sudah berlangsung secara turun temurun sebagai tradisi yang mengiringi pernikahan yang berasal dari daerah Jogjakarta. Bubak Kawah adalah upacara adat yang dilaksanakan ketika orang tua mantu pertama, ritual Bubak Kawah berlaku untuk pengantin perempuan dan laki-laki

\footnotetext{
${ }^{11}$ Suwarna Priggawidagda, hal, 276.
} 
yang merupakan anak pertama/sulung. Bila anak bungsu, dilakukan Tumplek Punjen. Secara bahasaBubak berarti mbukak (membuka), kawah artinya adalah air yang keluar sebelum kelahiran bayi, sedang secara istilah Bubak Kawah berarti: membuka jalan mantu atau mantu yang pertama. Bubak Kawah adalah upacara adat yang dilaksanakan ketika orang tua mantu pertama atau terakhir, mantu pertama disebut tumpak punjen, sedang mantu terakhir disebut tumplak punjen. Pelaksanaan ritual Bubak Kawah pada malam Midodareni, malam sebelum perayaan hajatan dan harus setelah ijab Qabul. Calon mempelai setelah melakukan siraman, kemudian mulailah dilakukan ritual Bubak Kawah.

\section{Analisis Nilai-Nilai Pendidikan Islam Dalam Tradisi Bubak KawahDi Desa Morosari}

Melihat dan awal perkembangan semula, mulai proses masuknya Islam ke tanah Indonesia, dan luar Jawa, hingga ke pulau Jawa, proses peyebaran ajaran dan nilai-nilai Islam, mernang terjadi akulturasi antara tradisi orisinalitas penduduk pribumi dengan nilai-nilai Islami, sehingga dengan kebiasaan dan cara pandang inilah, bahwasanya kerangka dasarnya dibangun atas dasar-dasar percampuran nilai Islam dan tradisi pribumi menjadi satu kesatuan yang utuh. Bahkan sampai detik in percampuran tersebut adalah salah satu hal yang menjadi ruh dalam tradisi masyarakat Indonesia.

Pendekatan-pendekatan secara kultural merupakan strategi yang efisisen dengan menggunakan simbol-simbol Jawa, mengingat masyarakat mayoritas di Indonesia adalah penduduk Jawa untuk menyatukan satu tujuan dalam pengernbangan metodologi pendidikan Islam. Karenanya pesantren sebagai lembaga pendidikan Islam tertua di tanah Jawa, seharusnyalah melakukan proses modernisasi dengan tidak melupakan inti ajaran Islam itu sendiri.Sementara itu pada aspek pendidikan, khususnya pendidikan Islam, bahwasanya pemikiran Gus Dur, tetap menyandarkan pada nilai-nilai tradisi yang melekat pada masyarakat, khususnya 
masyarakat Jawa yang masih kental dengan budaya dan tradisinya. Pendekatan kultural mi seyogianya menjadi pilihan strategi untuk mengembangkan, membina, dan mengarahkan pendidikan Islam. ${ }^{12}$

Dalam perkembangan dakwah Islam di Indonesia para penyiar Islam mendakwahkan ajaran Islam melalui bahasa budaya, sebagaimana dilakukan oleh para Wali Allah di tanah Jawa. Karena kehebatan Para Wali dalam mengemas ajaran Islam dengan bahasa budaya setempat, sehingga masyarakat tidak sadar bahwa nilain ilai Islam masuk dan menjadi tradisi dalam kehidupan sehari-hari mereka.

Tugas berikutnya para intelektual Islam adalah menjelaskan secara sistematik dan berkelanjutan upaya penetrasi yang sudah dilakukan oleh para pendahulunya. Integrasi nilai-nilai Islam ke dalam kehidupan bangsa Indonesia ternyata tidak sekedar masuk pada aspek kebudayaan semata, tetapi sudah masuk ke wilayah hukum. Sebagai contoh dalam hukum keluarga (akhwalulsyahsiyyah), masalah waris, masalah pernikahan. Nilai-nilai Islam telah masuk ke wilayah hukum yang berlaku di Indonesia. ${ }^{13}$

Setiap kali suatu agama datang pada suatu daerah, maka mau tidak mau, agar ajaran agama tersebut dapat diterima oleh masyarakatnya secara baik, penyampaian materi dan ajaran agama tersebut haruslah bersifat "membumi". Maksudnya adalah, ajaran agama tersebut harus menyesuaikan diri dengan beberapa aspek lokal, sekiranya tidak bertentangan secara diametris dengan ajaran substantif agama tersebut. Demikian pula dengan kehadiran Islam di Jawa, sejak awalnya, Islam begitu mudah diterima, karena para pendakwahnya menyampaikan Islam secara harmonis, yakni merengkuh tradisi yang baik sebagai bagian dari ajaran agama Islam sehingga masyarakat merasa "ngeh" atau "enjoy" menerima Islam menjadi agamanya. Umumnya, para pendakwah Islam dapat menyikapi tradisi lokal, yang dipadukan menjadi bagian dan tradisi yang "Islami", karena berpegang pada suatu kaidah

\footnotetext{
${ }^{12}$ Faisol, Pendidikan Islam Perspektif, hal. 210.

${ }^{13}$ Wahyudin, Pendidikan Agama Islam, hal. 122.
} 
ushuliyyah (kaidah yang menjadi pertimbangan yang perumusan hukum menjadi hukum fiqih), yang cukup terkenal, yakni: menjaga nilai-nilai lama yang baik, sembari mengambil nilai baru yang lebih baik

Dengan demikian, maka walaupun bisa dikatakan bahwa hal itu termasuk dalam kawasan religius atau ranah agama, namun perlu disadari bahwa aspek yang dominan adalah sebagai budaya suatu gugus masyarakat. Oleh karena itu, jika hal tersebut kemudian dinyatakan sebagai ritual keagamaan, seharusnya clipandang sebagai budaya keagamaan, bukan sebagai ajaran inti agama itu sendiri. Sehingga jika pun dilaksanakan, maka tidak mengapa, justru malah menambah syi'ar keagamaan. Sebaliknya, jika kemudian oleh sebagian orang (muslim) hal tersebut tidak dilaksanakan, juga tidak mengapa, karena bukan Sebagai bagian normative dari agama, yang penting bahwa substansi agama dalam pelaksanaan ritual kelahiran, pernikahan, dan kematian seorang muslim tetap dilaksanakan dan dijaga.

Sikap yang arif atau bijaksana diperlukan dalam mensikapi hal itu. Agama dan keberagamaan tidak akan hidup secara sejuk dalam masyarakat, jika tidak mengadopsi berbagai budaya yang baik (alsunnah al-tsaqafiyyah) bagi pengembangannya. Oleh karena itu perlu dipertimbangkan, bahwa jika unsur-unsur budaya dalam aspek lokalitas akan dicabut secara sistematis dan keseluruhan dari suatu agama, maka dapat dipastikan, yang terjadi adalah keburukan dalam bentuk pertentangan antagonis antar kelompok masyarakat.

Sementara dalam kaidah-kaidah ushuliyah (kaidah pokok) yang menjadi acuan sumber hukum fiqih, jelas dinyatakan bahwa mencegah berbagai keburukan, justru harus lebih diutamakan daripada sekedar membuat kebaikan. Dalam hal ini tekad untuk membersatukan agama dan berbagai anasir non-agama yang masuk dapat dipandang, paling tidak, sebagai fiat baik terhadap agama. Namun upaya menghilangkan aspeka-aspek lokalitas budaya yang masuk dalam agama sehingga suatu agama hanya membawa masuk budaya asing, di mana agama tersebut lahir, 
adalah suatu keburukan yang sangat besar, karena akan menimbulkan penolakan dan suatu masyarakat yang sudah memiliki akar tradisi kuatnya sendiri. Karena pentingnya pencegahan kemungkaran dan keburukan dalam kerja spiritual dan kerja lahiriyah keagamaan tersebut, maka dalam kaidah ushuliyah (ushul al-fiqh), justru pencegahan atas keburukan harus didahulukan daripada membuat kebaikan. ${ }^{14}$

Tradisi Bubak Kawah di Desa Morosari merupakan sebuah tradisi yang penuh dengan makna dan nilai-nilai pendidikan Islam yang luhur. Nilai - nilai pendidikan Islam ini dikemas dengan budaya Jawa yang tergambar dalam persyaratan, perlengkapan dan pelaksanaan tradisi Bubak Kawah. Hal ini senada dengan Suwarna priggawidagda bahwa tujuan dan makna nilai upacara Bubak Kawah adalah sebagai berkut:

a. Pernyataan syukur kepada Tuhan bahwa telah dapat mengawali mantu.

b. Permohonan kepada Tuhan agar pengantin diberikan kekuatan, kesegaran jasmani dan rohani, ayem tentrem.

c. Menunjukkan tanggung jawab orangtua terhadap putranya. Walaupun susah payah untuk melaksanakan perhelatan, tetapi badan dan pikiran tetap segar bugar seperti segarnya rujak degan.

Nilai pendidikan Islam yang pertama adalah rasa syukur kepada Allah dari orang tua pengantin karena rahmat Allah, anaknya diberi kemudahan untuk menemukan jodohnya, berjalan lancar sampai terlaksananya acara ijab qabul atau akad nikah. Oleh karena itu acara Bubak Kawah hanya boleh dilaksanakan setelah acara ijab qabul dilaksanakan. Dalam hal ini terdapat pendidikan akhlak kepada Allah untuk senantiasa bersyukur kepada Allah atas segala kemudahan dan rahmat yang diberikan.

Sedangkan nilai pendidikan Islam yang kedua yaitu permohonan kepada Tuhan agar pengantin diberikan kekuatan, kesegaran jasmani dan rohani, ayem tentrem. Hal ini apabila yang punya hajat atau mantu memiliki saudara kandung, sauadara kandung

\footnotetext{
${ }^{14}$ Muhammad Sholikin, Ritual Dan Tradisi Jawa, (Jogjakarta: Narasi, 2010), hal. 19-20.
} 
tersebut juga memiliki anak, tetapi belum pernah melaksanakan pernikahan, maka orang tua pengantin harus memberikan hadiah kepada saudara kandung berupa barang, biasanya berupa sarung atau pakaian dan diserahkan kepada saudara kandung orang tua pengantin pada saat acara Bubak Kawah dan meminta doa restu untuk melakukan acara nikah terlebih dahulu. Dalam tradisi ini terdapat nilai pendidikan yang mengajarkan kepada manusia untuk selalu menghormati orang yang lebih tua, andhap ashor, senantiasa meminta doa kepada yang lebih tua sebagai bentuk penghormatan kepada saudara yang lebih tua. Dalam tradisi menghormati ini terdapat nilai-nilai pendidikan karakter untuk saling menghormati terutama kepada orang yang lebih tua.

Nilai pendidikan yang selanjutnya juga terlihat dari berbagai perlengkapan yang digunakan dalam acara Bubak Kawah. Nilai- nilai pendidikan itu diwujudkan dalam berbagai benda yang digunakan. Wadah empluk dalam tradisi ini memiliki arti bawah sebuah pernikahan adalah sebuah wadah untuk kedua mempelai memulai kehidupan barunya untuk mengikuti sunnah rasulullah dan menyempurnakan agama Islam. Nilai pendidikan disini bahwa pernikahan adalah sebuah wadah dan tujuan untuk mendapat ridho Allah dan mengikuti sunnah rasul

Bawang merah satu dan bawah putih satu itu melambangkan dalam pernikahan itu dimulai dengan menyatukan lelaki dan perempuan yang dilambangkan dengan bawah merah dan bawang putih masing- masing satu dalam satu wadah yaitu pernikahan. Warna putih dari bawang putih melambangkan niat yang suci dalam pernikahan adalah untuk mendapat ridho Allah semata, sedangkan warna merah dari bawang merah melambangkan kesungguhan, kemauan keras untuk mandiri setelah menikah sampai kakek nekek. Pendidikan yang terkandung dalam beras biasa dan beras ketan adalah melambangkan bahwa setiap kelarga memiliki jatah rizki dalam keluarganya yang berbeda beda, ada yang memiliki jatah rizki banyak, ada yang sedikit, tapi jumlah rizki itu hakikatnya adalah dari Allah, maka meskipun mendapat rizki yang 
banyak atau sedikit harus tetap barsama dalam satu wadah dan dikembalikan pada niat semula bahwa pernikahan adalah untuk mencari ridho Allah semata

Biji kemiri dan biji kluwak adalah bumbu dapur yang memiliki rasa berbeda, yang satu asam yang satu pahit. Hal ini melambangkan dalam kehidupan keluarga nanti pasti akan mengalami pahit dan asamnya kehidupan. Hal ini pasti di alami oleh setiap keluarga yang baru menikah, maka meski pun dalam keadaan susah senang, pahit dan asam kehidupan ini, mereka harus tetap bersama, menyelasaikan semua masalah itu dalam wadah pernikahan. Secara mudahnya, bahwa dalam pernikahan itu jangan sampai ada perceraian meskipun memiliki masalah seberat apapun harus diselesaikan bersama.

Dalam kwali juga terdapat nilai pendidikan dalam rumah tangga dan juga masyarakat. Nasi pecel, potongan kelapa, garam, cabai, tempe mentah dan daun suruh melambangkan dalam kehidupan rumah tangga pengantin baru akan mengalami hal yang baru pula. Lingkungan yang baru, tugas dan tanggung Jawab yang baru, cara berfikir yang baru serta hal- hal lain terkait dengan masyarakat. Keanekaragam benda tersebut melambangkan dalam pernikahan akan menemukan banyak hal baru terkait tugas dan kewajiban suami istri dalam keluarga dan dalam masyarakat. Sedangkan jajanan pasar melambangkan kesederhanaan dalam kehidupan, karena jajanan pasar identik dengan harganya yang sangat murah, jadi dalam kehidupan hendaknya bersikap sederhana, tidak berlebih- lebihan dalam harta benda

Jadah dan dodol Jawa itu melambangkan dalam pernikahan itu akan terasa lengkap saat memiliki anak yang patuh dan halus pekertinya seperti rasa jadah, serta anak sholeh dan sholihah yang selalu mendoakan kedua orang tuanya seperti rasa dodol manis. Pisang yang digunakan diutamakan pisang raja karena memiliki nilai yang dilambangkan bahwa kelak diakhirat semua keluarga akan berkumpul bagai raja atau dalam bahasa lain masuk surga bersama- sama. 
Dalam membuka tradisi Bubak Kawah, selalu diawali dengan mengucap syahadat, hal ini bertujuan untuk selalu mengajak manusia ingat kepada Allah, memulia segala kegiatan apapun hanya untuk mengharap ridho Allah semata. Selain itu syahadat ini yang diperbaharui ini bertujuan untuk mempertebal keimanan kepada Allah, karena manusia adalah tempat lupa dan salah. Nilai- nilai ibadah juga terdapat saat sang bapak pengantin mengucapkan kepada istrinya bahwa benih (anak) yang dulu dititipkan dirahimnya adalah sari syahadat. Hal ini mengingatkan manusia bahwa anak adalah dari Allah, sedangkan kewajiban orang tua adalah menikahkan anaknya saat telah dewasa

Nilai pendidikan Islam yang ketiga yaitu menunjukkan tanggung Jawab orangtua terhadap putranya. Walaupun susah payah untuk melaksanakan perhelatan, tetapi badan dan pikiran tetap segar bugar seperti segarnya rujak degan. Hal ini terbukti saat kedua orang tua dan pengantin mengangkat empluk bersama dan kemudian makan isi empluk itu mengandung makna bahwa kehidupan rumah tangga itu terdiri dari mertua dan menantu, maka diantara keduanya harus bersama- sama dalam melaksanakan kehidupan dengan sikap rukun dan gotong royong saat sulit dan mudah. Hal ini menjadi penting karena banyak terjadi kasus mantu dan mertua saling bertengkar, maka dengan tradisi ini mengingatkan bahwa harus hidup rukun antara mantu dan mertua. Sedangkan kenduri itu menandung makna bahwa orang tua pengantin bersedekah dan meminta doa kepada yang hadir agar rumah tangga anaknya sakinah mawadah warahmah

Dalam tradisi Bubak Kawah di Desa Morosari memiliki nilai-nilai pendidikan aqidah untuk selalu mengharap ridho Allah, nilai-nilai ibadah dalam bersedekah, serta nilai akhlak berupa aklak kepada sesama manusia. Didalam tradisiBubak Kawah juga terdapat pendidikan ke-Islaman bagi para pengantin sebagai bekal untuk melaksanakan tugas dan kewajiban sebagai suami istri serta tugas dan kewajiban kepada masyaakat. 


\section{KESIMPULAN}

Nilai pendidikan Islam dalam tradisi Bubak Kawah di Desa Morosari yang pertama adalah rasa syukur kepada Allah dari orang tua pengantin karena rahmat Allah, anaknya diberi kemudahan untuk menemukan jodohnya, berjalan lancar sampai terlaksananya acara ijab qabul atau akad nikah. Nilai pendidikan Islam yang kedua yaitu permohonan kepada Tuhan agar pengantin diberikan kekuatan, kesegaran jasmani dan rohani, ayem tentrem. Hal ini apabila yang punya hajat atau mantu memiliki saudara kandung, sauadara kandung tersebut juga memiliki anak, tetapi belum pernah melaksanakan pernikahan. Nilai pendidikan yang ketiga terlihat dari berbagai perlengkapan yang digunakan dalam acara Bubak Kawah. Nilai-nilai pendidikan itu diwujudkan dalam berbagai benda yang digunakan. 


\section{Daftar pustaka}

Al-Maududi . Abdul A’ala.(1994). Dasar-Dasar Islam. Bandung: Pustaka.

Eksan, Moch.(2000) Kyai Kelana Biografi KH. Muchid Muzadi. Yogyakarta : Lkis.

Faisol. (2005). Pendidikan Islam Perspektif. Jakarta: Quepedia.

Faisol. (2005).Pendidikan Islam Perspektif. Jakarta: Quepedia.

Nur. Muhammad Abdul Hafizh. (1997)Mendidik Anak Bersama Rasullullah. Bandung: Albayan.

Priggawidagda. Suwarna.(2006) Tata Upacara Dan Wicana Pengantin Gaya Jogja.Jogjakarta: Kanisius.

Sholikin, Muhammad. (2010) Ritual Dan Tradisi Jawa. Jogjakarta: Narasi.

Suhemi, Mimin Emi. (2002) Etika \& Aplikasi. Jakarta: EGC.

Wahyudin. (2007) Pendidikan Agama Islam. Jakarta: Grasindo. 